\title{
Do SME Policy Improve Firm Productivity? Empirical Evidence from Latin America and China
}

\author{
Peiyuan $\mathrm{Xu}^{1}$ \\ ${ }^{1}$ School of Economics and Management, Tsinghua University, Beijing, China \\ Correspondence: Peiyuan Xu, School of Economics and Management, Tsinghua University, Beijing, Haidian \\ District, China.
}

Received: January 2, 2020

Accepted: January 29, 2020

Online Published: February 10, 2020

doi:10.5539/ibr.v13n3p47

URL: https://doi.org/10.5539/ibr.v13n3p47

\begin{abstract}
Based on World Bank Enterprise Survey dataset, this paper uses instrumental variables regression to examine whether Small and Medium Enterprises (SMEs) are more efficient and if SMEs policies (SME Policy) have any influence on firm-level Total Factor Productivity (TFP) in two important emerging economies: Latin America and the Caribbean (LAC) and China. The results show that, first, there is a positive correlation between firm size and TFP in LAC but not in China. Second, training, line of credit/loan for SMEs are proved to have a significant positive effect on firm TFP. Specifically, for Chinese firms, the training programs are most effective while for LAC firms, loan and credit are most effective. Third, R\&D related innovation improves the efficiency, especially for Chinese firms. Fourth, government shareholding improves efficiency in China since they may provide some help in acquiring loans, while in LAC countries, the government shareholding has a negative effect. Based on above mentioned results, I suggest that Latin American countries should set financial relaxing as the primary goal of SME policies and China should provide more training programs and improve incentive mechanism in technology innovation for SMEs.
\end{abstract}

Keywords: total factor productivity, SME policy, efficiency

\section{Introduction}

\subsection{Economic Growth and SMEs}

Small and Medium-sized Enterprises (SMEs, sometimes MSMEs when Micro enterprises are also included) play an important role in economy. In Organisation for Economic Cooperation and Development (OECD) countries, SMEs generate about $60 \%$ of employment and 50\% 60\% of value added (OECD, 2019); in China, MSMEs generate $50 \%$ of fiscal income, $60 \%$ of GDP, $70 \%$ of technology innovation, $80 \%$ of urban employment and constitute 90\%, according to Chinese Vice Premier of the State Council-LIU He (Jinshizhijia, 2018); in Latin America, SMEs constitute $80 \%-90 \%$ of all firms. Apart from the fact that SMEs are majority in numbers and provide abundant jobs, the existence of SMEs contributes to the social cohesion at regional and local level since most of their employees are from middle- and low-income groups.

\subsection{SME Programs and Rationale}

Intuitively, SMEs are most dynamic, innovative, flexible and thus the most efficient cells in every economy. Countless successful firms used to be small and could have bankrupted at early stages. Given the magnitude and social importance of SMEs, governmental and non-governmental organizations have been allocating abundant resources to SMEs. For example, the majority of Latin American countries provides abundant and diversified beneficial policies to SMEs (Ibarraran, Maffioli, \& Stucchi, 2009). These policies provide help to SMEs against a range of problems, such as labor training (provided by public sector or private sector), innovation, trade, cluster, credit and others. The funding may come from public sector or private sector. The Chinese government, on the other hand, provide similar MSME policies/programs (I use policy and program interchangeably in this article) but more attention is allocated to the problem of financial constraint on SMEs. In April 2019, Chinese central government issued the "Guidance on Promoting A Healthy Development of SMEs" to require local government and financial institution to carry out preferential financial, fiscal and industrial policy for SMEs. The situation for SMEs in OECD countries is relatively better, in 2017, a higher percentage of SMEs reported that they no longer saw access to financial resource as a main obstacle with a reduction in rejection rate and there is a notable 
expansion in the use of alternative financing instruments by SMEs.

Though SME policy gives the hope of a higher and more efficient growth rate, little is known about their true effectiveness. Since larger firms are proved successful firms while MSMEs are not, it is natural to expect a lower profitability and probably a lower efficiency in general. Using Total Factor Productivity (TFP) as an indicator for efficiency, LAC countries and China suffer a significant efficiency gap compared to U.S. The problem for Latin American countries is that the overall relative efficiency is declining since 1970s (Ferreira Pedro, Pesseôa Samuel De, \& Veloso Fernando, 2012). For example, in 1960, the Latin America the TFP had a relative TFP level of $81 \%$ compared to U.S. while in 2007 this number dropped to 0.54 . While for China and India suffer the problem of severe misallocation without which the TFP level of these two countries would be $30 \%-60 \%$ higher (Hsieh \& Klenow, 2009). In China, similar SME polices are being promoted. From the end of 2018, Chinese president XI Jinping has mentioned in different situation the importance of small and medium-sized enterprises, as well as private firms. In accordance of this idea, in April 2019, Chinese central government implemented the idea by issuing the "Guidance on Promoting A Healthy Development of SMEs", require local government and financial institution to carry out preferential financial, fiscal and industrial policy for SMEs. These means more credit will be provided, less requirement to get loans and a friendlier environment. In general, more resource will be allocated to SMEs.

However, all these policies are based on one but crucial assumption: SMEs should be as efficient as Large Enterprises (LEs) and Mega Enterprises (MEs) at least. This paper thinks that before taking it as granted, it is necessary to think its validity. There're two main reasons to do so. First, the underlying TFP is average SMEs productivity instead of individual firm TFP. Certainly, successful SMEs are much more efficient and productive than LEs or MEs and these successful SMEs eventually become LEs or MEs. One should not forget that the majority of the SMEs are unsuccessful with a below average efficiency and profitability. If the unsuccessful SMEs are large in number (very possibly they are), then the average TFP will be lower than that of LEs or MEs. Second, many of SMEs are startups. Naturally, newly-established firms have a higher risk of bankruptcy and will definitely be lower in efficiency. This will induce a natural gap of average TFP between two group of firms. I name this hypothetic value of efficiency gap between SMEs and LEs Reasonable Efficiency Gap. So, the contribution of SME policy is to push back the average SME efficiency back to the hypothetic level and no more. The decreasing marginal efficiency return is because a certain fraction of startups will be definitely of low efficiency and bankrupt. Unfortunately, a robust estimate of the hypothesized efficiency level of LEs/SMEs or Reasonable Efficiency Gap is not provided. I use another method to test if the efficiency gap is the smallest. Since the SME policy are most effective when the marginal TFP enhance effect is zero or negative, when SME policy can still improve firm level TFP, it is useful and the efficiency gap is not at the optimal value; otherwise, SME policy are producing negative effect since these resources are be used in other area.

LAC and China are chosen as research area not only because both areas are in the developing world but also they have very distinct features in ideology and institution. Therefore, it will allow the control of more factors to get a better estimate of the Reasonable Efficiency Gap. The structure of this paper is as follows. Section 1 sketches the background, literature review and hypothesis; Section 2 describes the methodology and data; Section 3 reports the main results; Section 4 discusses the robustness and policy suggestions.

\subsection{Literature Review}

\subsubsection{SME and SME Programs}

SME policies are those targeted at firms below a certain size (Ibarraran et al., 2009). These policies are designed to give certain preferential treatment(s) to the targeted enterprises, such as tax reduction, subsidies, credit facilities, administrative help, staff training and others.

SMEs are believed to have certain advantages and thus SME policies should be implemented. First, due to market imperfection, SMEs are at a disadvantage in terms of getting credit, investing R\&D etc. When SMEs who have positive NPV projects but are financially constrained, these firms have to forego these growth opportunities and make less contribution to the gross GDP as they could have. Second, since SMEs are larges in number, there's sufficient competition within SMEs and with LEs, which guarantees a strong effective market and uncompetitive are soon wed out (Ibarraran et al., 2009). Third, due to reasons other than efficiency-enhancing, some SME policies exist fully or partially to guarantee employment and reduce inequality. Fourth, SMEs are mostly labor intensive so they provide more jobs relative to LEs (Almeida \& Aterido, 2010; Ayyagari, Beck, \& Demirguckunt, 2007; OECD, 2019). Lastly, vastly distributed SMEs contribute the social integration.

Opponents of the SME policy are skeptical on SMEs' superiority. If the efficiency superiority is just an illusion, 
the reallocation of fiscal resources is a poor choice. They argue that such industrial policies distort resource allocation and hamper economic efficiency. Due to the subsidy, low efficient firms survive longer than they should. When low efficient SMEs are the majority, their aggregate negative effect will dominate. Besides, the innovation advantage of SMEs does not have foundation since the R\&D investment made by SMEs are far less then that made by LEs.

\subsubsection{Firm Size and TFP}

Total Factor Productivity (TFP) is one of the most important sources of economic growth apart from the physical and human capital accumulation. About half of the international per capita income gap is explained by TFP (Hall \& Jones, 1999; Klenow \& Rodríguez-Clare, 1997; Prescott, 1998; Restuccia, 2013). As Paul Krugerman said, Productivity isn't everything, but in the long run it is almost everything.

The relationship between firms and TFP level have been examined by a dozen of scholars and yet no consensus has been reached nor the causality has been identified. Due to the heterogeneous data limitation, most current studies can only focus SMEs in one country or region. The results on firm size and TFP are mixed. Pitt and Lee (1981) found a positive correlation between firm size and efficiency in Indonesia's weaving industry. Page (1984) found a positive correlation between enterprise size and efficiency in the Indian machine tool industry. Little, Mazumdar, and M Page Jr (1987) found that enterprise efficiency was positively correlated with firm size in Indian mechanical tool industry. Haddad and Harrison (1993) found that firm size of Moroccan manufacturing enterprises was positively correlated with TFP (they also found that the introduction of foreign capital could reduce the efficiency difference). Brada, King, and Ma (1997) found a positive correlation between enterprise scale and efficiency in the nonferrous metallurgy, chemical industry, wood (processing), metal processing, textile, and food industries in the Czech Republic and Hungary. Taymaz and Saatci (1997) found a positive correlation between enterprise size and efficiency in Turkish cement and automobile industry. Lundvall and Battese (2000) found a positive correlation between enterprise scale and efficiency in Kenya's manufacturing industry. Alvarez and Crespi (2003) found that the scale of Ghana's manufacturing enterprises was positively correlated with efficiency. Taymaz (2005) found a positive correlation between enterprise efficiency and firm size in 22 Turkish manufacturing sub-industries. IDB (2010) found a positive correlation between enterprise efficiency and size in Colombia (1982-1998), el Salvador (2004) and Mexico (2004).

On the other hand, evidence supporting that LEs are less efficient than SMEs is also abundant. Page (1984) found a negative correlation between firm size and efficiency in Indian soap, printing, clothing and other industries. Chen and Tang (1987) found that the firm size in Taiwan's electronics industry is not correlated to efficiency. Little et al. (1987) found a negative correlation between size and efficiency in Indian soap, shoe making, printing, metal casting and other industries. Biggs, Shah, and Srivastava (1995) found inverted U/V structure relationship between firm size and productivity in Ghana, Kenya and Zimbabwe. The pattern is as follows: when the number of employees is less than 199, the firm efficiency positively is correlated to firm size; when the number of employees is higher than 199, the relationship turns negative. Brada et al. (1997) found no significant relationship in ferrous metallurgy, electrical and electronics devices, construction materials in Czechoslovakia and also no significant relationship in ferrous metallurgy, ceramics, handicraft manufacture and other industries in Hungary. Taymaz (2005) found a positive correlation between efficiency and scale in 22 industries of Turkish manufacturing industry, but also found a negative correlation in 10 industries, and no correlation in 36 industries. Beck, Demirguc-Kunt, and Levine (2005) didn't find robust evidence that GDP per capita growth rate is positively correlated to the SME sector importance in 45 countries when endogeneity was considered, but the causality is not well verified, neither the poverty alleviation effect is detected. In the same book of IDB (2010), enterprise size is negatively correlated with efficiency in Chile (2006), Uruguay (2005), Venezuela (2001) and Bolivia (2000), and finally, enterprise size is not correlated with efficiency in Ecuador (2005) and Argentina (1997-2002). Restuccia (2013) find the relative gap in TFP is the main reason why Latin America can't maintain a sustainable growth rate and the inadequate industrial policies were the main cause. Restuccia and Rogerson (2013) further pointed out that very few Latin American governments established a quality of feedback and evaluation system for SME policies, except Chile and Peru (Goldberg \& Palladini, 2008). Busso, Madrigal, and Pagés (2013) provide further evidence that the resource misallocation might be cause of the stagnation of efficiency growth in Latin America. In China, the firm size was discovered to be negatively correlated with TFP, since the resource was inadequately excessively allocated to the inefficient big state-owned enterprises (SOE) firms who are subjected to multitask theory (Bai, Li, Tao, \& Wang, 2000; Bai, Lu, \& Tao, 2006; Hsieh \& Klenow, 2009). Table 1 summarizes the results.

In sum, it is hard to say if SMEs have any advantages over LEs (Large Enterprises) and if there's some gap, whether this gap is at an acceptable range. 
Table 1. Literature on firm size and efficiency

\begin{tabular}{|c|c|c|c|}
\hline Author(s)\&year & Country & Period & Correlation \\
\hline Pitt and Lee (1981) & Indonesia: weaving industry & $1972 / 3,1975$ & + \\
\hline Page (1984) & India: soap, printing, clothing, machine tools & 1980 & $\begin{array}{l}+: \text { Machine tools } \\
\text { Null: others }\end{array}$ \\
\hline Chen and Tang (1987) & Taiwan, China: electronics & 1980 & Null \\
\hline Little et al. (1987) & $\begin{array}{l}\text { India: soap, shoes, printing, machine tools, } \\
\text { metal casting }\end{array}$ & $1978-80$ & $\begin{array}{l}+: \text { Machine tools } \\
\text { Null: Other }\end{array}$ \\
\hline Haddad and Harrison (1993) & Morocco: manufacturing & $1985-1989$ & + \\
\hline Biggs et al. (1995) & $\begin{array}{l}\text { Ghana, Kenya, Zimbabwe: food, timber, } \\
\text { textiles, metals }\end{array}$ & $1992-1993$ & $\begin{array}{l}\text {-: LEs } \\
+: \text { SMEs }\end{array}$ \\
\hline Mengistae (1996) & Ethiopia: manufacturing & 1993 & + \\
\hline Brada et al. (1997) & $\begin{array}{l}\text { Czech Republic, Slovenia, Hungary: } \\
\text { manufacturing }\end{array}$ & $1990-1991$ & $\begin{array}{l}+: 9 \text { industries } \\
-: 3 \text { industries }\end{array}$ \\
\hline Taymaz and Saatci (1997) & Turkey: textiles, cement, lime, automobiles & 1987-1992 & $\begin{array}{l}+: 2 \text { industries } \\
\text { Null: } 1 \text { industry }\end{array}$ \\
\hline Lundvall and Battese (2000) & Kenya: manufacturing & 1993-1995 & + \\
\hline Alvarez and Crespi (2003) & Chile: manufacturing & & $\begin{array}{l}+ \\
+: 22 \text { industries }\end{array}$ \\
\hline Taymaz (2005) & Turkey: manufacturing & $1987-1997$ & $\begin{array}{l}-: 10 \text { industries } \\
\text { Null: } 36 \text { industries }\end{array}$ \\
\hline $\begin{array}{l}\text { Beck, Demirguc-Kunt, and Levine } \\
(2005)\end{array}$ & 45 countries & $1990-2000$ & \\
\hline Yang and Chen (2009) & Taiwan, China: electronics industry & 2001 & $\begin{array}{l}+: \text { size not } \\
\text { controlled } \\
\text {-: size controlled }\end{array}$ \\
\hline IDB (2010) & Latin America: manufacturing & $1997-2006$ & $+/-$ \\
\hline Restuccia (2013) & Latin America & 1960-2009 & - \\
\hline
\end{tabular}

1.4 Hypotheses and Research Design

Based on existing literature and in order to gauge the TFP gap between SMEs and LEs, the first set of hypotheses is design to test that if the firm size is correlated to TFP and if the directions are opposite in Latin America and China.

\section{H1a: SME TFP level is positively correlated to firm size in Latin America}

H1b: TFP level is negatively correlated firm size in China

The second hypothesis will test if SME policies have any positive effect on firm level TFP. However, currently there's no detailed SME policies available to see how specifically when and how SMEs are affected by these policies/programs/instruments. Therefore, this paper adopts the same method used by Ibarraran et al. (2009). Since most SME policies provide three types of help: credit line, training, and innovation, information of these indicator can tell us if SMEs are helped by SME policies. Since Latin America and China have different economic institution, I predict that SME policies have positive effect on SME TFP level for firms in China but a negative effect on SME TFP level for firms in Latin America.

H2a: SME policies have positive effect on firms in China

H2b: SME policies have negative TFP enhancing effect on firms in Latin America

In order to measure if the TFP enhancing effect differs across SMEs and LEs, grouped regression are used.

H3: SME policies' TFP enhancing effect are larger on SMEs while smaller in LEs

\section{Methodology}

Since efficient firms tend to have better financial situation and have more ability to invest in training, innovation and other productivity related activities, the variables we use to proxy SME policies will be endogenous. In order to alleviate the endogeneity, I construct an instrument variable- the proportion of firms reporting training, credit, innovation in the same industry and country for all three endogenous variables respectively, as Ibarraran et al. (2009) did. It is logic to think that the proportion of firms reporting training, credit line and innovation in the same industry and country is correlated to the result of training, credit or innovation activity of each firm but uncorrelated to individual firm level TFP.

\subsection{Model}

According to Ibarraran et al. (2009), the model is as follows:

$$
\text { TFP }_{i}=\alpha+\beta_{1} \text { train }_{i}+\beta_{2} \text { credit }_{i}+\beta_{3} \text { innov }_{i}+\beta_{4} \text { size }_{i}+\beta_{5} \text { Inage }_{i}+\beta_{6} \text { burea }_{i}+\beta_{7} \text { union }_{i}+\beta_{8} \text { suby }_{i}+\beta_{9} \text { soe }_{i}+\beta_{10} \text { cou }
$$




$$
n \text { try }_{i}+\beta_{11} \text { indcd }_{i}+\beta_{12} \text { year }_{i}+\varepsilon_{i}
$$

Instead of a panel data, a cross-section dataset is employed. Subscript i stands for the position of observation in the dataset. The justification for opting for a cross-sectional instead of panel data structure is because, firstly, observations are only available in year 2006, 2009, 2010, 2012, 2016 and 2017, since World Bank team cannot survey a country every year thus observation in each year differs a lot. For example, for 2006 we have 4345 observations and for 2009 only 947 and for 2016 only 360. Secondly and most importantly, which is also the reason why observations differ a lot across year, there's no guarantee that the same firm will be surveyed in mentioned years. Therefore, the cross-sectional regression became the only option.

\subsection{Data}

The dataset used is provided by World Bank Enterprise Surveys (WBES). This database provides establishment-level data based on a representative sample of firms in the non-agricultural economy. The dataset covers 128 countries and I only kept 31 Latin America and the Caribbean countries and China. The sample starts from 2006 to 2017 but it is not continuous, only observations in 2006, 2009, 2010, 2012, 2016 and 2017 are covered. Firms are all from manufacture sector distributed in 16 subinsdustries. ${ }^{1}$ In total, there're 11823 observations, including 4305 small ( $<20)$ firms, 4581 medium (20 99) firms and 2937 large (>=100) firms.

\subsection{Variables and Statistics}

$T_{F P}$ stands for the log value of firm's TFP. WBES provides two set of revenue-based TFP values. Both methods assume a common production technology within industry and make estimates by industry. The difference lies in the production function. The first (tfprYKLM) assumes that the total output $\mathrm{Y}$ comes from capital $\mathrm{K}$, labor $\mathrm{L}$ and material $\mathrm{M}$ while the second (tfprVAKL) assumes that the value added (VA) comes from capital $\mathrm{K}$ and labor $\mathrm{L}$. The difference between these two variables are small and given the fact that the sample are all manufacture firms, tfprYKLM is used.

train $_{i}$ is the percentage of permanent full-time production employees who received formal training in last fiscal year;

credit $t_{i}$ is a dummy variable and takes value 1 if the establishment has a line of credit or loan from a financial institution and takes 0 otherwise; SME-credit $t_{i}$ is a dummy variable and takes value 1 if the establishment has a line of credit or loan from a financial institution due to the result of SME program and takes 0 otherwise. This latter variable is constructed and used in regression to proxy the loans or credit granted that is a result of SME polies. $S M E$-credit ${ }_{i}$ is generated based on the following rule: since whether the establishment had been granted a line of credit/loan is observed and what types of collateral (and approximate percentage value of all collateral) is required, a SME-credit is a credit that does not require land, buildings under ownership of the establishment, machinery and equipment including movables. However, this type of credit may still require other types of collaterals, such as accounts receivable and inventories, personal assets of owner (house etc.) and others. In 11823 observations, 55\% establishments observations have acquired line of credit or loan from financial institution, only 18 firms obtained the loan without providing any type of collateral, 1312 (20\%) firms obtained the loan under SME programs.

inno $_{i}$ is a dummy and takes value 1 if the establishment had expense on R\&D other than market research; age $_{i}$ represents how many years the establishment has been in operation;

size $_{i}$ is a dummy variable representing. Small(<20), Medium(20-99), Large(100 And Over); ${ }^{2}$

suby $y_{i}$ is a dummy variable and takes 1 if the establishment is a branch of another firm and takes 0 otherwise;

soe $_{i}$ is the percentage of shares owned by government/state;

burea $_{i}$ represents the percentage time the senior management spent in dealing with govt regulations;

union $_{i}$ represents the percentage of workforce unionized;

country $_{i}$ indcd $_{i}$ and year ${ }_{i}$ are dummy variables to control the macro-economic environment at certain country, manufacture subindustry and year.

According to correlation test, the absolute value of any two pair correlation coefficient is smaller than 0.4. Variance inflation factor (VIF) test is also executed, mean VIF is 1.14. Therefore, there no multicollinearity problems in the sample. Weak instrument test (Cragg-Donald Wald F statistic) and under-identification test (Anderson canon. corr. LM statistic) are also performed. 
Table 2. Statistic Summary

\begin{tabular}{|c|c|c|c|c|c|c|c|c|c|}
\hline Variable & Obs & & & Mean & & Std. Dev. & Min & & Max \\
\hline \multicolumn{10}{|c|}{ size $=$ Small $(<20)$} \\
\hline TFP & 4,305 & & \multicolumn{3}{|c|}{2.48} & 1.24 & -3.90 & \multicolumn{2}{|r|}{9.51} \\
\hline age & 4,305 & & \multicolumn{3}{|c|}{19.32} & 14.70 & 0.00 & \multicolumn{2}{|r|}{146.00} \\
\hline soe & 4,305 & & \multicolumn{3}{|c|}{0.19} & 3.92 & 0.00 & \multicolumn{2}{|r|}{100.00} \\
\hline SME_credit & 4,305 & & \multicolumn{3}{|c|}{0.09} & 0.29 & 0.00 & \multicolumn{2}{|r|}{1.00} \\
\hline inno & 4,305 & & \multicolumn{3}{|c|}{0.23} & 0.42 & 0.00 & \multicolumn{2}{|r|}{1.00} \\
\hline burea & 4,305 & & \multicolumn{3}{|c|}{13.00} & 18.86 & 0.00 & \multicolumn{2}{|r|}{100.00} \\
\hline train & 4,305 & & \multicolumn{3}{|c|}{21.44} & 38.33 & 0.00 & \multicolumn{2}{|r|}{100.00} \\
\hline suby & 4,305 & & \multicolumn{3}{|c|}{0.05} & 0.22 & 0.00 & \multicolumn{2}{|r|}{1.00} \\
\hline union & 4,305 & & \multicolumn{3}{|c|}{4.05} & 18.96 & 0.00 & \multicolumn{2}{|r|}{100.00} \\
\hline \multicolumn{10}{|c|}{ size $=$ Medium (20-99) } \\
\hline TFP & 4,581 & & \multicolumn{3}{|c|}{2.53} & 1.39 & -4.79 & \multicolumn{2}{|r|}{8.44} \\
\hline age & 4,581 & & \multicolumn{3}{|c|}{23.33} & 17.70 & 0.00 & & 210.00 \\
\hline soe & 4,581 & & & 0.59 & & 7.09 & 0.00 & & 100.00 \\
\hline SME_credit & 4,581 & & & 0.12 & & 0.33 & 0.00 & & 1.00 \\
\hline inno & 4,581 & & & 0.38 & & 0.49 & 0.00 & & 1.00 \\
\hline burea & 4,581 & & & 13.29 & & 17.90 & 0.00 & & 100.00 \\
\hline train & 4,581 & & & 39.43 & & 43.95 & 0.00 & & 100.00 \\
\hline suby & 4,581 & & & 0.11 & & 0.32 & 0.00 & & 1.00 \\
\hline union & 4,581 & & & 5.78 & & 20.98 & 0.00 & & 100.00 \\
\hline & & & & $\mathrm{e}=$ Large $(10$ & and Ove & & & & \\
\hline TFP & 2,937 & & & 2.71 & & 1.49 & -3.63 & & 7.92 \\
\hline age & 2,937 & & & 30.49 & & 24.29 & 0.00 & & 340.00 \\
\hline soe & 2,937 & & & 0.72 & & 7.33 & 0.00 & & 95.00 \\
\hline SME_credit & 2,937 & & & 0.12 & & 0.33 & 0.00 & & 1.00 \\
\hline inno & 2,937 & & & 0.55 & & 0.50 & 0.00 & & 1.00 \\
\hline burea & 2,937 & & & 13.05 & & 17.85 & 0.00 & & 100.00 \\
\hline train & 2,937 & & & 57.00 & & 41.51 & 0.00 & & 100.00 \\
\hline suby & 2,937 & & & 0.26 & & 0.44 & 0.00 & & 1.00 \\
\hline union & 2,937 & & & 6.80 & & 21.78 & 0.00 & & 100.00 \\
\hline Table 3. Cor & relation & & & & & & & & \\
\hline & TFP & age & soe & SME_credit & $\mathrm{RD}$ & burea & train & suby & union \\
\hline TFP & 1 & & & & & & & & \\
\hline age & -0.0334 & 1 & & & & & & & \\
\hline soe & 0.0562 & -0.017 & 1 & & & & & & \\
\hline SME_credit & -0.0152 & 0.0182 & -0.0241 & 1 & & & & & \\
\hline inno & 0.0283 & 0.0928 & -0.0337 & 0.0495 & 1 & & & & \\
\hline burea & -0.0317 & 0.0539 & -0.046 & 0.0399 & 0.0133 & 1 & & & \\
\hline train & 0.0523 & 0.0201 & 0.0882 & 0.0126 & 0.2647 & -0.016 & 1 & & \\
\hline suby & 0.0567 & 0.097 & 0.0006 & 0.003 & 0.0985 & 0.0391 & 0.0919 & 1 & \\
\hline union & -0.036 & 0.0947 & -0.0085 & -0.0231 & 0.0475 & 0.0143 & -0.0119 & 0.0718 & 1 \\
\hline
\end{tabular}

\section{Results}

\subsection{The Efficiency Gap Across and within China and LAC Countries}

In average, China has a $62 \%$ TFP advantage over LAC countries. This number is calculated by transforming the average (log) TFP level value of Chinese establishments (2.99) and that of LAC (2.51) back to natural exponential value. However, since the TFP data for China is only available for year 2012, while for LAC countries the 2012 value is not available. Since China implemented the " 4 trillion (RMB)" fiscal expansion project since 2009 and the long shadow fiscal stimulus did not come to an end until 2016. There is evidence showing that since 2013 to 2016, the overall productivity in China was decreasing (Bai, Hsieh, \& Song, 2016). Therefore, the lag overall TFP gap between China and LAC may not persist until 2017. More information is needed to discuss the efficiency gap between China and LAC after 2012.

In China and LAC countries, the average TFP gap between SMEs and LEs -23\% (SMEs TFP - LEs TFP). This means that in general, SMEs is less efficient than LEs. In China, the estimated Rational TFP gap is $-30 \%$ and in LAC, $-16 \%$. Within LAC countries, Argentina, Chile, Mexico, Peru are countries with a less efficient SME 
sectors, with TFP gap over $20 \%$ and are significant at $5 \%$ or $1 \%$ significance level; there're countries with a more efficient SME sector but the none of them can pass T-test.

Table 4. TFP gap with China and LAC countries

\begin{tabular}{|c|c|c|c|c|c|c|c|}
\hline Country & TFP gap & $\mathrm{t}$ & $\mathrm{p}$ & Country & TFP gap & $\mathrm{t}$ & $\mathrm{p}$ \\
\hline Argentina & $49 \%$ & 3.92 & 0.00 & Guyana & $-14 \%$ & -0.36 & 0.64 \\
\hline Bolivia & $-15 \%$ & -0.92 & 0.82 & Honduras & $25 \%$ & 1.07 & 0.14 \\
\hline Brazil & $-4 \%$ & -0.32 & 0.62 & Jamaica & $56 \%$ & 1.47 & 0.07 \\
\hline Chile & $46 \%$ & 4.76 & 0.00 & Mexico & $35 \%$ & 3.34 & 0.00 \\
\hline Colombia & $16 \%$ & 1.84 & 0.03 & Nicaragua & $18 \%$ & 1.20 & 0.12 \\
\hline Costa Rica & $15 \%$ & 0.46 & 0.32 & Paraguay & $8 \%$ & 0.26 & 0.40 \\
\hline Dominican Republic & $-5 \%$ & -0.23 & 0.59 & Peru & $23 \%$ & 2.15 & 0.02 \\
\hline Ecuador & $11 \%$ & 0.79 & 0.22 & Trinidad and Tobago & $-9 \%$ & -0.22 & 0.59 \\
\hline El Salvador & $2 \%$ & 0.25 & 0.40 & Uruguay & $-46 \%$ & -2.59 & 0.99 \\
\hline Guatemala & $5 \%$ & 0.40 & 0.34 & China & $30 \%$ & 2.56 & 0.01 \\
\hline
\end{tabular}

Note: $\mathrm{T}$ value is obtained by grouped T-tests with unequal variance since LEs are larger in number.

\subsection{SME Policy and TFP}

The correlation between TFP level and all 3 types of SME polices-training, credit and innovation also gives us some information on the different situation in LAC and China. Training program can enhance labor productivity due to the application of better working habits. In China, a positive correlation between the percentage of formal employees trained and establishment TFP level is observed, however, in LAC countries, there is basically no such correlation.

Relaxing financial constraint can be another more important way of helping out SMEs. However, it is difficult to identify what percentage of credit is granted due to SME programs and what percentage is granted based on normal indicators, such as collateral, NPV, ROE, etc. The indicator SME-credit is an imperfect proxy but is the only available indicator. The correlation shows that in China, small and medium firms SME-related credit have a significant lower TFP level than their competitors who received credit/loan that required more solid collaterals (land, building), this understandable since the latter may have a better financial situation and be more efficient firms. In LAC countries, SME-related credit seems has no impact on the efficiency. One common effect for SME-related credit/loan is that the variance of firm TFP was significantly reduced. (Figure 2. TFP and SME related credit programs)

Lastly, by using whether the establishment has an internationally-recognized quality certification as an indicator of innovation related SME programs, no evidence is found that they're correlated. (Figure 3. TFP and Innovation)

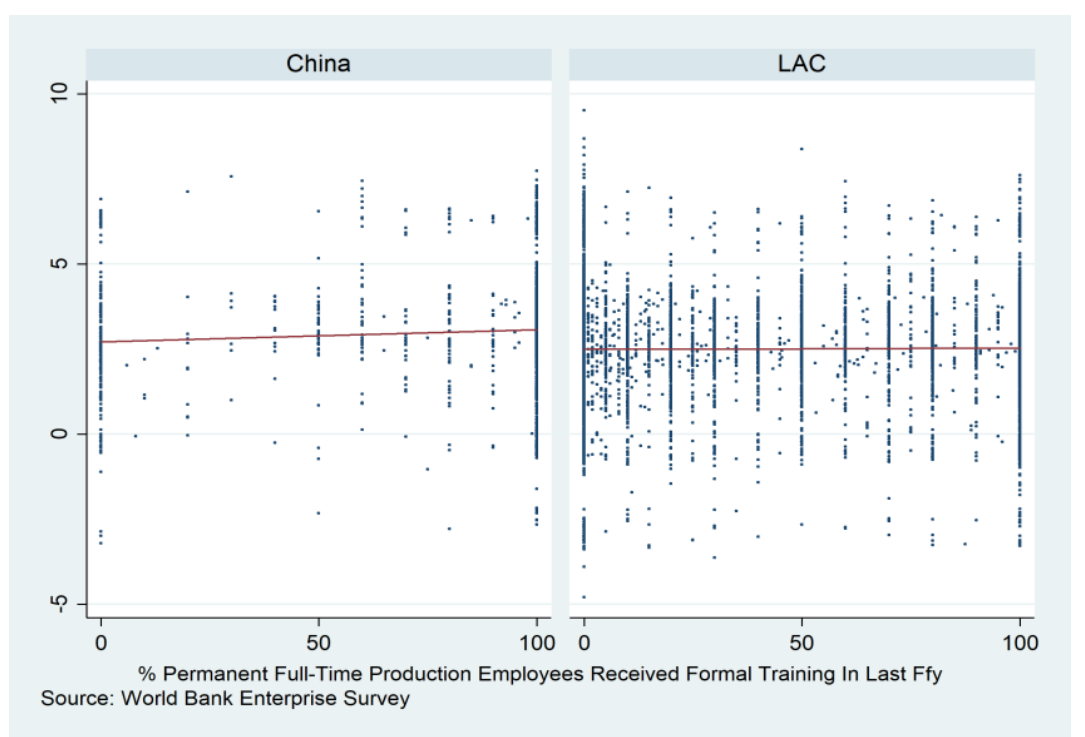

Figure 1. TFP and SME employee training programs 


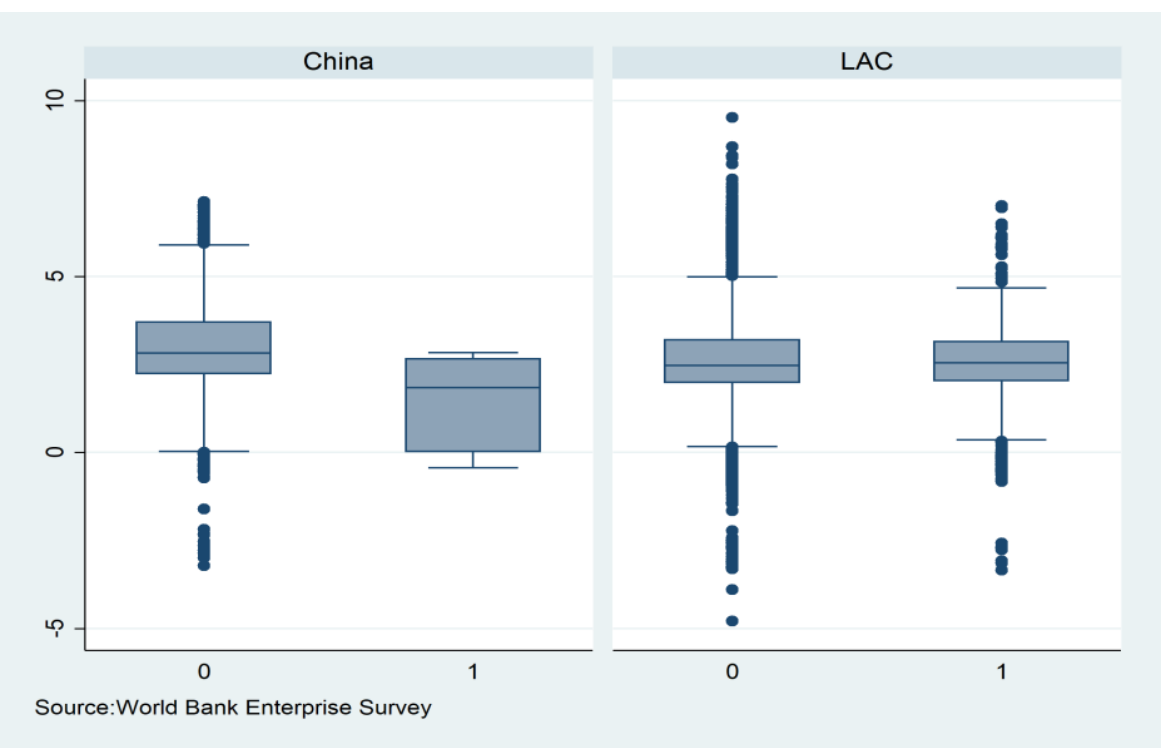

Figure 2. TFP and SME related credit programs

Note: 0 stands for observations without receiving SME-related financing but received other credit financing, 1 stands for observations without receiving SME-related financing. Firms recently didn't apply for line of credit/loan or were granted credit/loan are not included.

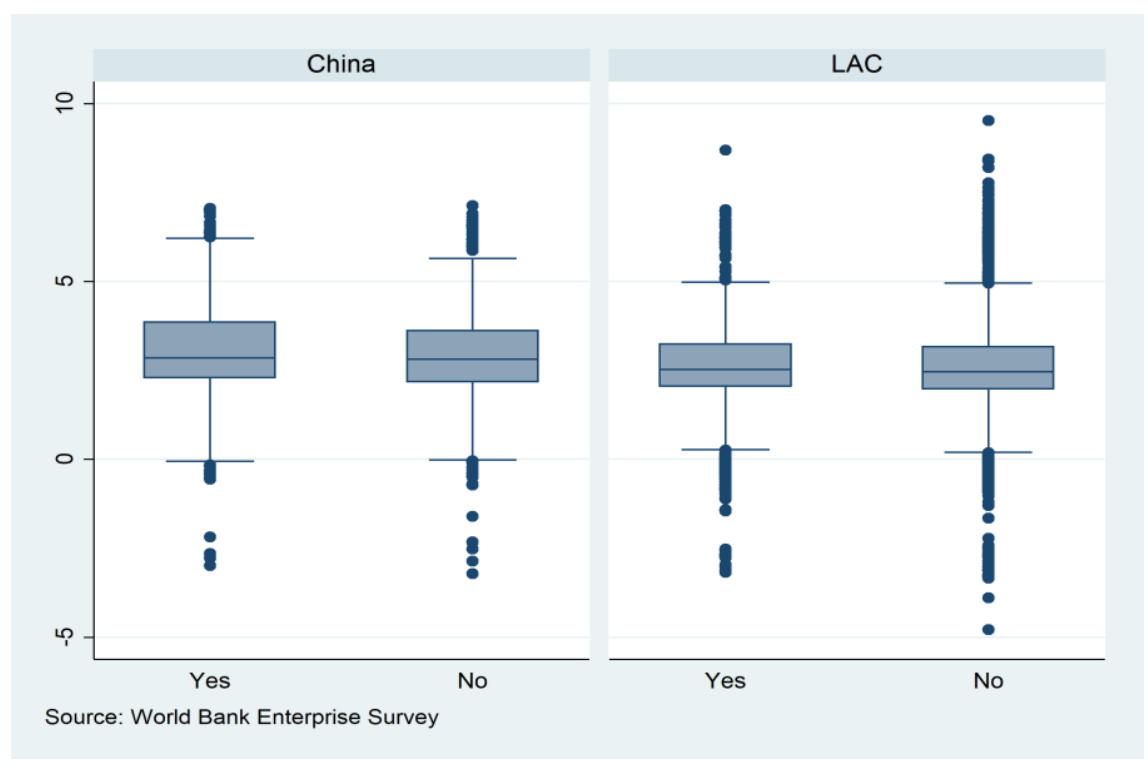

Figure 3. TFP and Innovation

\subsection{Effectiveness of SME Policies}

Since train, credit and innovation are endogenous variables, I use the fraction of firms reporting that they received train/credit/innovation in the same industry and country as corresponding instrument variable, as Ibarraran et al. (2009) did. First, OLS regression is performed as a baseline test in column (1)-(4) of Table 5. Determinants of Firm TFP. However, since OLS regression suffers the endogeneity problem, I will focus on the IV regression results in column (8) of Table 5. Determinants of Firm TFP in which, year, country and industry dummy are all controlled and the goodness of fit is the highest.

First, all three types of SME policies have positive impacts on firm TFP. Training has a positive but limited effect on firm TFP: $1 \%$ more employee trained, the firm TFP increase is less than $0.001 \%$. The coefficient is significant at 5\% significance level. SME related line of credit/loan also has positive effect on firm TFP: $1 \%$ more employee trained, the firm TFP increase is $0.039 \%$ and significant at $10 \%$ significance level; innovation ( $R \& D$ investment) has positive effect on firm TFP but is not significant.

Second, bigger firms tend to have higher TFP. Medium and large firms do have an efficiency advantage over 
small firms. Medium/Large firms are $0.066 \% / 0.092 \%$ more efficient than small firm in terms of TFP. Both coefficients are significant at $1 \%$ significance level.

Lastly, soe, union, and suby are proved to have some positive effect on TFP, while age and burea basically have no effect on TFP. Fraction of shares owned by government (soe) has a positive effect on TFP, $1 \%$ of soe share fraction means a $0.005 \%$ higher TFP. the coefficient is significant at $1 \%$ significance level. Firm age (lnage) has no effect on TFP, the coefficient cannot pass T-test. The percentage of senior management time spent in dealing with government regulations (burea) has no effect on TFP, the coefficient cannot pass T-test. The percentage of labors unionized (union) has a positive effect on TFP: $1 \%$ more labors unionized means a $0.001 \%$ TFP increase. The coefficient is significant at $1 \%$ significance level. Whether the establishment is subsidiary (suby) has a positive effect on TFP. the parent companies are $0.07 \%$ lower in TFP. The coefficient is significant at $1 \%$ significance level.

Table 5. Determinants of Firm TFP

\begin{tabular}{|c|c|c|c|c|c|c|c|c|}
\hline & (1) & (2) & (3) & (4) & (5) & (6) & (7) & (8) \\
\hline & OLS & OLS & OLS & OLS & IV & IV & IV & IV \\
\hline train & $0.001 * * *$ & $0.001 * *$ & 0.000 & -0.000 & $0.001 * *$ & $0.001 * * *$ & $\begin{array}{l}0.000 \\
0.001)\end{array}$ & $0.000 * *$ \\
\hline & $(0.000)$ & $(0.000)$ & $(0.000)$ & $(0.000)$ & $(0.000)$ & $(0.000)$ & $\begin{array}{l}(0.001) \\
0.028\end{array}$ & $\begin{array}{l}(0.000) \\
0.039 *\end{array}$ \\
\hline SME_credit & $\begin{array}{l}-0.076 * * \\
(0.038)\end{array}$ & $\begin{array}{l}-0.070 * \\
(0.037)\end{array}$ & $\begin{array}{l}0.010 \\
(0.038)\end{array}$ & $\begin{array}{l}0.005 \\
(0.015)\end{array}$ & $\begin{array}{l}-0.058 \\
(0.063)\end{array}$ & $\begin{array}{l}-0.015 \\
(0.020)\end{array}$ & $\begin{array}{l}0.028 \\
(0.065)\end{array}$ & $\begin{array}{l}0.039 * \\
(0.020)\end{array}$ \\
\hline Inno & $\begin{array}{l}0.019 \\
(0.028)\end{array}$ & $\begin{array}{l}0.036 \\
(0.028)\end{array}$ & $\begin{array}{l}0.061 * * \\
(0.029)\end{array}$ & $\begin{array}{l}0.008 \\
(0.011)\end{array}$ & $\begin{array}{l}0.071 * * \\
(0.033)\end{array}$ & $\begin{array}{l}-0.048 * * * \\
(0.012)\end{array}$ & $\begin{array}{l}0.155 * * * \\
(0.034)\end{array}$ & $\begin{array}{l}0.013 \\
(0.012)\end{array}$ \\
\hline Medium & $\begin{array}{l}0.034 \\
(0.029)\end{array}$ & $\begin{array}{l}0.043 \\
(0.029)\end{array}$ & $\begin{array}{l}0.026 \\
(0.029)\end{array}$ & $\begin{array}{l}0.073 * * * \\
(0.012)\end{array}$ & $\begin{array}{l}0.031 \\
(0.029)\end{array}$ & $\begin{array}{l}0.092 * * * \\
(0.013)\end{array}$ & $\begin{array}{l}0.010 \\
(0.029)\end{array}$ & $\begin{array}{l}0.066 * * * \\
(0.012)\end{array}$ \\
\hline Large & $\begin{array}{l}0.191 * * * \\
(0.036)\end{array}$ & $\begin{array}{l}0.194 * * * \\
(0.037)\end{array}$ & $\begin{array}{l}0.143 * * * \\
(0.038)\end{array}$ & $\begin{array}{l}0.106 * * * \\
(0.015)\end{array}$ & $\begin{array}{l}0.171 * * * \\
(0.039)\end{array}$ & $\begin{array}{l}0.139 * * * \\
(0.016)\end{array}$ & $\begin{array}{l}0.115 * * * \\
(0.039)\end{array}$ & $\begin{array}{l}0.092 * * * \\
(0.016)\end{array}$ \\
\hline soe & & $\begin{array}{l}0.011 * * * \\
(0.002)\end{array}$ & $\begin{array}{l}0.008 * * * \\
(0.002)\end{array}$ & $\begin{array}{l}0.005^{* * * *} \\
(0.001)\end{array}$ & $\begin{array}{l}0.011^{* * * *} \\
(0.002)\end{array}$ & $\begin{array}{l}0.006 * * * \\
(0.001)\end{array}$ & $\begin{array}{l}0.009 * * * \\
(0.002)\end{array}$ & $\begin{array}{l}0.005 * * * \\
(0.001)\end{array}$ \\
\hline lnage & & $\begin{array}{l}-0.081 * * * \\
(0.016)\end{array}$ & $\begin{array}{l}-0.031 * \\
(0.016)\end{array}$ & $\begin{array}{l}-0.004 \\
(0.007)\end{array}$ & $\begin{array}{l}-0.081 * * * \\
(0.016)\end{array}$ & $\begin{array}{l}-0.018 * * * \\
(0.007)\end{array}$ & $\begin{array}{l}-0.033 * * \\
(0.016)\end{array}$ & $\begin{array}{l}-0.004 \\
(0.007)\end{array}$ \\
\hline burea & & $\begin{array}{l}-0.002 * * * \\
(0.001)\end{array}$ & $\begin{array}{l}-0.000 \\
(0.001)\end{array}$ & $\begin{array}{l}0.000 \\
(0.000)\end{array}$ & $\begin{array}{l}-0.002 * * * \\
(0.001)\end{array}$ & $\begin{array}{l}-0.000 \\
(0.000)\end{array}$ & $\begin{array}{l}-0.001 \\
(0.001)\end{array}$ & $\begin{array}{l}0.000 \\
(0.000)\end{array}$ \\
\hline union & & $\begin{array}{l}-0.003 * * * \\
(0.001)\end{array}$ & $\begin{array}{l}-0.002 * \\
(0.001)\end{array}$ & $\begin{array}{l}0.001 * * * \\
(0.000)\end{array}$ & $\begin{array}{l}-0.003^{* * * *} \\
(0.001)\end{array}$ & $\begin{array}{l}0.001 * * * \\
(0.000)\end{array}$ & $\begin{array}{l}-0.002^{*} \\
(0.001)\end{array}$ & $\begin{array}{l}0.001 * * * \\
(0.000)\end{array}$ \\
\hline suby & & $\begin{array}{l}0.195 * * * \\
(0.041)\end{array}$ & $\begin{array}{l}0.242 * * * \\
(0.041)\end{array}$ & $\begin{array}{l}0.073 * * * \\
(0.017)\end{array}$ & $\begin{array}{l}0.192 * * * \\
(0.041)\end{array}$ & $\begin{array}{l}0.083 * * * \\
(0.017)\end{array}$ & $\begin{array}{l}0.236 * * * \\
(0.042)\end{array}$ & $\begin{array}{l}0.070 * * * \\
(0.017)\end{array}$ \\
\hline Constant & $\begin{array}{l}2.475 * * * \\
(0.031)\end{array}$ & $\begin{array}{l}2.934 * * * \\
(0.068)\end{array}$ & $\begin{array}{l}3.511 * * * \\
(0.207)\end{array}$ & $\begin{array}{l}1.268 * * * \\
(0.057)\end{array}$ & $\begin{array}{l}2.948 * * * \\
(0.071)\end{array}$ & $\begin{array}{l}1.145 * * * \\
(0.033)\end{array}$ & $\begin{array}{l}3.585 * * * \\
(0.207)\end{array}$ & $\begin{array}{l}1.274 * * * \\
(0.058)\end{array}$ \\
\hline Obs & 11,823 & 11,820 & 11,820 & 11,820 & 11,820 & 11,820 & 11,820 & 11,820 \\
\hline $\operatorname{Adj} R^{2}$ & 0.006 & 0.014 & 0.038 & 0.847 & 0.014 & 0.836 & 0.037 & 0.847 \\
\hline Prob $>$ F & 0.000 & 0.000 & 0.000 & 0.000 & 0.000 & 0.000 & 0.000 & 0.000 \\
\hline Country & $\mathrm{NO}$ & NO & YES & YES & NO & $\mathrm{NO}$ & YES & YES \\
\hline Year & $\mathrm{NO}$ & NO & YES & YES & NO & $\mathrm{NO}$ & YES & YES \\
\hline Industry & $\mathrm{NO}$ & NO & NO & YES & $\mathrm{NO}$ & YES & $\mathrm{NO}$ & YES \\
\hline
\end{tabular}

Note: Robust standard errors in parentheses, ${ }^{* * *} \mathrm{p}<0.01,{ }^{* *} \mathrm{p}<0.05,{ }^{*} \mathrm{p}<0.1$

\section{Discussion and Policy Suggestions}

Based on previous results, H1a (SME TFP level is positively correlated to firm size in Latin America), H2b (SME policies have negative TFP enhancing effect on firms in Latin America) and H2b (SME policies have negative TFP enhancing effect on firms in Latin America) have been proved, while H1b (TFP level is negatively correlated firm size in China) is only partially proved since I found no significant relationship between TFP and SME polies instead of negative relationship.

In order to measure if the TFP enhancing effect differs across SMEs and LEs, grouped regression are used.

\subsection{SME Policy Difference in China and LAC}

In Table 5. Determinants of Firm TFP, I pooled observations from China and LAC countries in one regression. However, the form and mechanism through which these policies may differ across countries. Then I re-estimated the coefficients by region (China and LAC). The results are as follows:

First, training programs for Chinese firms are effective but not for LAC countries. Perhaps in China, very few enterprises provide training programs for their worker, since due to the excessive labor supply they can always hire other working forces with higher human capital instead of training them.

Second, the SME related line of credit/loan exhibits no significant effect on Chinese firms but shows significant 
and positive effect on LAC firms. This means that in this area, the overall efficiency can be improved by helping out financially distressed SMEs.

Third, the innovation seems to have no impact on TFP either in China or LAC.

Lastly, the fraction of state shareholding's effect on TFP is different across regions: in China, firms with more government shareholding are more efficient; while in LAC, more private firms are more efficient. This is reasonable since given that only partially state-owned firms are included. The TFP of firms with $100 \%$ national shareholding may be lower due to their multitask nature.

Table 6. Country Difference in Determinants of Firm TFP

\begin{tabular}{|c|c|c|c|c|c|c|}
\hline & (1) & (2) & (3) & (4) & (5) & (6) \\
\hline & IV & IV & IV & IV & IV & IV \\
\hline & China & China & LAC & LAC & LAC & LAC \\
\hline \multirow[t]{2}{*}{ train } & $0.005^{* * *}$ & $0.001 * *$ & -0.001 & 0.000 & -0.000 & 0.000 \\
\hline & $(0.002)$ & $(0.000)$ & $(0.001)$ & $(0.000)$ & $(0.001)$ & $(0.000)$ \\
\hline \multirow[t]{2}{*}{ SME_credit } & $-1.014 * *$ & 0.015 & -0.019 & 0.008 & 0.030 & $0.037 *$ \\
\hline & $(0.417)$ & (0.109) & $(0.063)$ & $(0.020)$ & $(0.065)$ & $(0.020)$ \\
\hline \multirow[t]{2}{*}{ inno } & 0.134 & -0.022 & $0.105 * * *$ & $-0.031 * *$ & $0.170 * * *$ & 0.022 \\
\hline & $(0.116)$ & $(0.031)$ & $(0.034)$ & $(0.013)$ & $(0.036)$ & $(0.013)$ \\
\hline \multirow[t]{2}{*}{ medium } & -0.156 & 0.001 & 0.028 & $0.087 * * *$ & 0.025 & $0.070 * * *$ \\
\hline & $(0.164)$ & $(0.043)$ & $(0.029)$ & $(0.013)$ & $(0.029)$ & $(0.013)$ \\
\hline \multirow[t]{2}{*}{ large } & 0.067 & 0.071 & $0.140 * * *$ & $0.122 * * *$ & $0.112 * * *$ & $0.089 * * *$ \\
\hline & $(0.171)$ & $(0.045)$ & $(0.040)$ & $(0.017)$ & $(0.040)$ & $(0.017)$ \\
\hline \multirow[t]{2}{*}{ soe } & $0.009 * * *$ & $0.006 * * *$ & 0.001 & $-0.005 * *$ & -0.001 & $-0.004^{* *}$ \\
\hline & $(0.003)$ & $(0.001)$ & (0.004) & $(0.002)$ & $(0.005)$ & $(0.002)$ \\
\hline \multirow[t]{2}{*}{ suby } & -0.036 & 0.013 & $-0.235 * * *$ & $-0.108 * * *$ & $-0.263 * * *$ & $-0.082 * * *$ \\
\hline & $(0.200)$ & $(0.043)$ & $(0.041)$ & $(0.018)$ & $(0.041)$ & $(0.018)$ \\
\hline \multirow[t]{2}{*}{ lnage } & 0.061 & 0.032 & $-0.060 * * *$ & -0.005 & $-0.037 * *$ & -0.006 \\
\hline & $(0.104)$ & $(0.027)$ & $(0.016)$ & $(0.007)$ & $(0.016)$ & $(0.007)$ \\
\hline \multirow[t]{2}{*}{ burea } & $0.035^{*}$ & -0.003 & -0.001 & $0.001 * *$ & -0.001 & 0.000 \\
\hline & $(0.021)$ & $(0.004)$ & $(0.001)$ & $(0.000)$ & $(0.001)$ & $(0.000)$ \\
\hline \multirow[t]{2}{*}{ union } & & & $-0.002 * * *$ & $0.001 * * *$ & $-0.001 *$ & $0.001 * * *$ \\
\hline & & & $(0.001)$ & $(0.000)$ & $(0.001)$ & $(0.000)$ \\
\hline \multirow[t]{2}{*}{ Constant } & $2.537 * * *$ & $1.135 * * *$ & $2.967 * * *$ & $1.140 * * *$ & $3.628 * * *$ & $1.307 * * *$ \\
\hline & $(0.370)$ & $(0.095)$ & $(0.071)$ & $(0.036)$ & $(0.207)$ & $(0.060)$ \\
\hline Obs & 1,190 & 1,190 & 10,630 & 10,630 & 10,630 & 10,630 \\
\hline $\operatorname{Adj} R^{2}$ & 0.010 & 0.930 & 0.007 & 0.819 & 0.029 & 0.829 \\
\hline Country & NO & NO & NO & NO & YES & YES \\
\hline Year & $\mathrm{NO}$ & $\mathrm{NO}$ & $\mathrm{NO}$ & $\mathrm{NO}$ & YES & YES \\
\hline Industry & $\mathrm{NO}$ & YES & $\mathrm{NO}$ & YES & $\mathrm{NO}$ & YES \\
\hline
\end{tabular}

Note: Robust standard errors in parentheses, $* * * \mathrm{p}<0.01, * * \mathrm{p}<0.05, * \mathrm{p}<0.1$

\subsection{SME Policy on SMEs}

Now, I exclusively run the regression on SMEs to test H3 (SME policies' TFP enhancing effect are larger on SMEs while smaller in LEs). The results remain qualitatively the same as in Table 5. Determinants of Firm TFP.

\subsection{Limitations and Policy Suggestions}

There're two most important limitations of this research. First, due to the data limitation, there's no possibility to discuss the causality of any specific SME programs: how they are designed, how they are implemented and how they are evaluated. Second, the firms chosen may not be a sufficient representative sample of the true (size) firm size distribution. If it is not, then the applicability of this research is discounted.

Suggestions for governments. Based on above differentiated results, Chinese governments should design a better incentive for SMEs in technology innovation, while LAC governments should continue providing sufficient financial support to SMEs as well as guarantee a full implementation of this project, and both regions should enhance the level and quality of labor training in order to enhance TFP level.

\section{References}

Almeida, R. K., \& Aterido, R. (2010). The Investment in Job Training: Why Are SMEs Lagging So Much Behind? IZA Discussion Paper, 4486. https://doi.org/10.1596/1813-9450-5358

Alvarez, R., \& Crespi, G. (2003). Determinants of Technical Efficiency in Small Firms. Small Business Economics, 20(3), 233-244. https://doi.org/10.1023/A:1022804419183

Ayyagari, M., Beck, T., \& Demirguckunt, A. (2007). Small and Medium Enterprises Across the Globe. Small 
Business Economics, 29(4), 415-434. https://doi.org/10.1007/s11187-006-9002-5

Bai, C. E., Hsieh, C. T., \& Song, Z. (2016). The Long Shadow of China's Fiscal Expansion. Brookings Papers on Economic Activity, 129-165. https://doi.org/10.1353/eca.2016.0027

Bai, C. E., Li, D. D., Tao, Z., \& Wang, Y. (2000). A Multitask Theory of State Enterprise Reform. Journal of Comparative Economics, 28(4), 716-738. https://doi.org/10.1006/jcec.2000.1681

Bai, C. E., Lu, J., \& Tao, Z. (2006). The Multitask Theory of State Enterprise Reform: Empirical Evidence from China. American Economic Review, 96(2), 353-357. https://doi.org/10.1257/000282806777212125

Beck, T., Demirguc-Kunt, A., \& Levine, R. (2005). SMEs, Growth, and Poverty: Cross-Country Evidence. Journal of Economic Growth, 10(3), 199-229. https://doi.org/10.1007/s10887-005-3533-5

Biggs, T., Shah, M., \& Srivastava, P. (1995). Technological Capabilities and Learning in African Enterprises, World Bank.

Brada, J. C., King, A. E., \& Ma, C. Y. (1997). Industrial Economics of the Transition: Determinants of Enterprise Efficiency in Czechoslovakia and Hungary. Oxford Economic Papers, 49(1), 104-127. https://doi.org/10.1093/oxfordjournals.oep.a028593

Chen, T. J., \& Tang, D. P. (1987). Comparing technical efficiency between import-substitution-oriented and export-oriented foreign firms in a developing economy. Journal of Development Economics, 26(2), 277-289. https://doi.org/10.1016/0304-3878(87)90030-7

Ferreira Pedro, C., Pesseôa Samuel De, A., \& Veloso Fernando, A. (2012). On the Evolution of Total Factor Productivity in Latin America. Economic Inquiry, 51(1), 16-30.

https://doi.org/10.1111/j.1465-7295.2011.00430.x

Haddad, M., \& Harrison, A. (1993). Are there positive spillovers from direct foreign investment? Evidence from panel data for Morocco. Journal of Development Economics, 42(1), 51-74. https://doi.org/10.1016/0304-3878(93)90072-U

Hsieh, C. T., \& Klenow, P. J. (2009). Misallocation and Manufacturing TFP in China and India. The Quarterly Journal of Economics, 124(4), 1403-1448. https://doi.org/10.1162/qjec.2009.124.4.1403

Ibarraran, P., Maffioli, A., \& Stucchi, R. (2009). SME Policy and Firms' Productivity in Latin America. IZA Discussion Paper, 4486. Retrieved from https://papers.ssrn.com/sol3/papers.cfm?abstract_id=1493862

IDB. (2010). The Age of Productivity: Transforming Economies from the Bottom Up (1st ed.). New York, United States: PALGRAVE MACMILLAN.

Jinshizhijia. (2018). Data released on the contribution of SMEs to GDP, tax revenue and employment account for half of China's economy. Retrieved from http://www.lux88.com/gold/201808/522618.html

Little, I., Mazumdar, D. M., \& Page, J. J. (1987). Small Manufacturing Enterprises: A Comparative Analysis of India and Other Economies. Oxford University Press.

Lundvall, K., \& Battese, G. E. (2000). Firm size, age and efficiency: Evidence from Kenyan manufacturing firms. The Journal of Development Studies, 36(3), 146-163. https://doi.org/10.1080/00220380008422632

Mengistae, T. (1996). Age-size effects in productive efficiency: a second test of the passive learning model. Working Paper Series. 96-2. Centre for the Study of African Economies. Institute of Economics and Statistics, University of Oxford. Retrieved from https://EconPapers.repec.org/RePEc:csa:wpaper:1996-02

OECD. (2019). Financing SMEs and Entrepreneurs 2019. OECD.

Page, J. M. (1984). Firm size and technical efficiency: Applications of production frontiers to Indian survey data. Journal of Development Economics, 16(1), 129-152. https://doi.org/10.1016/0304-3878(84)90104-4

Pitt, M. M., \& Lee, L. F. (1981). The measurement and sources of technical inefficiency in the Indonesian weaving industry. Journal of Development Economics, 9(1), 43-64. https://doi.org/10.1016/0304-3878(81)90004-3

Restuccia, D. (2013). The Latin American Development Problem: An Interpretation. Economía, 13(2), 69-100. Retrieved from http://www.jstor.org/stable/23608145

Taymaz, E. (2005). Are Small Firms Really Less Productive? Small Business Economics, 25(5), 429-445. https://doi.org/10.1007/s11187-004-6492-x

Taymaz, E., \& Saatci, G. (1997). Technical Change and Efficiency in Turkish Manufacturing Industries. Journal 
of Productivity Analysis, 8(4), 461-475. https://doi.org/10.1023/A:1007796311574

Yang, C. H., \& Chen, K. H. (2009). Are Small Firms Less Efficient? Small Business Economics, 32(4), 375-395. https://doi.org/10.1007/s11187-007-9082-x

Notes

Note 1 . There're actually 22 subindustries covered. However, some subindustries are very closely interconnected and firm's primary business can cover a longer part in the value chain. Therefore, WBES re-classify some closely related subindustries as one subindustry. For example, Manufacture of motor vehicles, trailers and semi-trailers (ISIC 34) and Manufacture of other transport equipment (ISIC 35) are counted as one subindustry (ISIC 3435).

Note 2. There are other criteria. IDB (2010) divided Latin American enterprises by number of formal employees into 5 categories: micro (1-19), small (20-49), medium (50-99), large (100-249) and mega (250 and above) enterprises. China classifies firm size differently according to industry. Industrial enterprises are classified into 4 categories jointly according to the number of employees and sale value: Micro (less than 20 people or income less than 3 million yuan); small (more than 20 people and more than 3 million operating income); medium (more than 300 people and more than 20 million operating income) and large enterprises (more than 1000 in employees or more than 400 million yuan in operating income). Alternative variables include 11(num. permanent, full-time employees at end of last fiscal year).

\section{Copyrights}

Copyright for this article is retained by the author(s), with first publication rights granted to the journal.

This is an open-access article distributed under the terms and conditions of the Creative Commons Attribution license (http://creativecommons.org/licenses/by/4.0/). 